\title{
Influence of the synergy between mineral additions and Portland cement in the physical-mechanical properties of ternary binders
}

\author{
Á. Fernández ${ }^{\mathrm{a}}$, M.C. Alonso ${ }^{\mathrm{a}} \bowtie$, J.L. García-Calvo ${ }^{\mathrm{a}}$, B. Lothenbach ${ }^{\mathrm{b}}$ \\ a. Eduardo Torroja Institute for Construction Science, IETcc-CSIC, (Madrid, Spain) \\ b. Empa, Swiss Federal Laboratories for Materials Science and Technology, Laboratory for Concrete and \\ Construction Chemistry (Dübendorf, Switzerland) \\ Amcalonso@ietcc.csic.es
}

\begin{abstract}
The paper deals with the synergistic effect of mineral additions on the physical-mechanical performance of ternary blends prepared with different Portland cements (PC). The effect in setting and heat flow release is also analyzed. The mineral additions used are blast furnace slag (BFS), fly ash (FA) and limestone filler (LF). PCs with different $\mathrm{C}_{3} \mathrm{~A}$ and alkali content have been tested to study the synergy in ternary blends. Ternary binders with $\mathrm{PC}$ low in $\mathrm{C}_{3} \mathrm{~A}$ and alkali content achieve similar mechanical strength gain as plain PC and refinement of pore size distribution from early hydration ages due to the acceleration of $\mathrm{PC}$ hydration induced by the mineral additions. In contrast, ternary binders with $\mathrm{PC}$ higher in $\mathrm{C}_{3} \mathrm{~A}$ and alkali content have a delayed in mechanical strength at early hydration ages, but significantly higher at long hydration times.
\end{abstract}

KEYWORDS: Blended cement; Hydration; Physical properties; Mechanical properties

Citation/Citar como: Fernández, Á.; Alonso, M.C.; García-Calvo, J.L.; Lothenbach, B. (2016) Influence of the synergy between mineral additions and Portland cement in the physical-mechanical properties of ternary binders. Mater. Construcc. 66 [324], e097. http://dx.doi.org/10.3989/mc.2016.10815.

RESUMEN: Prestaciones físico-mecánicas en cementos ternarios dependiendo de la sinergia entre las adiciones minerales y el cemento Portland. El artículo aborda la interacción sinérgica de las adiciones minerales en el rendimiento físico-mecánico de mezclas ternarias preparadas con dos tipos de cemento Portland (PC). Se analiza desde las edades tempranas la contribución en los tiempos de fraguado y en el flujo de calor liberado. Las adiciones minerales usadas son escoria de alto horno, ceniza volante y filler calizo. Los PC utilizados se han seleccionado en base al contenido en $\mathrm{C}_{3} \mathrm{~A}$ y álcalis. Mezclas formuladas con $\mathrm{PC}$ de bajo contenido en $\mathrm{C}_{3} \mathrm{~A}$ y álcalis mantienen desde el inicio una ganancia similar en las prestaciones mecánicas y un refinamiento en el tamaño de poro atribuido a la aceleración inducida por las adiciones minerales en la hidratación inicial del PC. En cambio, mezclas ternarias con un $\mathrm{PC}$ con mayor contenido en $\mathrm{C}_{3} \mathrm{~A}$ y álcalis tienen más lenta generación de resistencias mecánicas iniciales, pero mayores a medida que avanza la hidratación.

PALABRAS CLAVE: Cementos con adiciones; Hidratación; Propiedades físicas,; Propiedades mecánicas

Copyright: (C) 2016 CSIC. This is an open-access article distributed under the terms of the Creative Commons Attribution License (CC BY) Spain 3.0.

\section{INTRODUCTION}

Cement production in the world is estimated at around 4.3 billion tones in 2014 (1) and it is expected to increase in the future. The manufacture of Portland cement clinker is responsible for about $5-8 \%$ of total $\mathrm{CO}_{2}$ emitted into the atmosphere $(2,3)$, in fact per ton of PC produced about 1 ton of $\mathrm{CO}_{2}$ is emitted $(3,4)$. The high environmental impact of clinker production can be reduced by partial or 
total replacement of clinker with mineral additions, by use of alternative fuels or by optimization of the heat transfer in the production of clinker (5).

The replacement of clinker by mineral additions can be total, as in the alkali activated blends (6-8), or partial, as in the blended cements like CEM II type ( $\mathrm{PC}$ clinker $>65 \%$ ) plus one mineral addition according to EN 197-1:2011. In fact, in Europe in the last years the CEM II production is twice that CEM I (9) and will increase in next years. The most common mineral additions employed are blast furnace slag (BFS), fly ash (FA), limestone filler (LF) and silica fume ( $\mathrm{SF}$ ). It is well known that the use of these mineral additions in binary mixes have technical, economic and environmental advantages (10-14) but their content is limited since the BFS and especially FA have slower reaction than clinker with the subsequent retardation of developing of technical properties of concrete $(13,15,16)$.

Recent studies with ternary blends (PC plus two mineral additions) have demonstrated that they can improve the mechanical performance with respect to binary binders at initial and long-term ages of hydration. This effect is more relevant when additions with different hydration mechanism are combined $(11,15,17-23)$. The future of CEN (European Committee for Standardization) is on the way to include the ternary blends in the standards (9).

Results reported in the literature for ternary blends suggest that the effect of the additions depends on the type of PC used $(16,21)$. Different studies showed that ternary blends using PC with relatively high alkali and $\mathrm{C}_{3} \mathrm{~A}$ content had lower initial mechanical strength than plain $\mathrm{PC}(5,18,19,22,24)$, while in mixes with PC containing low alkali and/or
$\mathrm{C}_{3} \mathrm{~A}$ content this effect is less relevant $(11,15,20,21$, $23,25)$. Dehuai and Zhaoyuan (24) found that in ternary blends composed of 50-70\% PC with $8 \% \mathrm{C}_{3} \mathrm{~A}$ and $0.9 \% \mathrm{Na}_{2} \mathrm{O}_{\mathrm{eq}}$. mixed with BFS and FA resulted in 32-59\% lower compressive strength than for the plain PC after 7 days of hydration. In contrast, Menéndez et al. (15) saw that ternary blends using PC with $2 \% \mathrm{C}_{3} \mathrm{~A}, \mathrm{LF}$ and BFS showed better strength than binary blends and similar than plain PC during hydration from 1 to 90 days, which were attributed to the LF at early ages and to the BFS hydration at long term $(11,15,21)$. The good mechanical strength of the ternary blends at long term has been also related to the refinement of the pore structure (21-23) which has a further positive response on durability (26). Besides, present authors in a previous paper (21) found that ternary blends with high blended content formed more $\mathrm{C}-\mathrm{S}-\mathrm{H}$ that contained more $\mathrm{Al}$ and less C/S ratio than C-S-H gels formed with plain PC and retained more alkalis in their structure.

The goal of this paper is to analyze the synergistic effect of the combination of two mineral additions (BFS, FA and/or LF) and the type of PC on the early hydration and on the physical-mechanical properties of ternary binders in order to clarify the discrepancies between authors.

\section{MATERIALS AND METHODS}

Two types of CEM I, that belong to the categories CEM I 42.5 R-SR and CEM I 42.5 R, were used to prepare the blends. The chemical compositions are reported in Table 1. X-ray fluorescence (XRF) was used for element content determination. Both PCs had small $\mathrm{CaCO}_{3}$ content, determined from

TABLE 1. Chemical and mineralogical composition and $\mathrm{CaCO}_{3}$ content (wt. \%) of the raw materials

\begin{tabular}{|c|c|c|c|c|c|}
\hline$\%$ & $\mathrm{PC}_{\mathrm{L}}$ & $\mathbf{P C}_{\mathrm{H}}$ & LF & BFS & FA \\
\hline $\mathrm{Na}_{2} \mathrm{O}$ & 0.2 & 0.1 & 0.6 & 0.4 & 0.8 \\
\hline $\mathrm{K}_{2} \mathrm{O}$ & 0.3 & 0.9 & 2.7 & 0.5 & 4.5 \\
\hline $\mathrm{Na}_{2} \mathrm{O}_{\mathrm{eq}}$ & 0.4 & 0.7 & 2.3 & 0.7 & 3.7 \\
\hline $\mathrm{CaO}$ & 60.3 & 63.3 & 26.1 & 45.5 & 3.6 \\
\hline $\mathrm{SiO}_{2}$ & 17.4 & 19.6 & 21.4 & 36.6 & 52.0 \\
\hline $\mathbf{A l}_{2} \mathbf{O}_{3}$ & 4.7 & 5.5 & 7.8 & 10.4 & 24.9 \\
\hline $\mathrm{Fe}_{2} \mathrm{O}_{3}$ & 5.1 & 2.4 & 2.6 & 0.3 & 6.3 \\
\hline MgO & 1.8 & 0.8 & 5.8 & 7.5 & 1.7 \\
\hline $\mathrm{SO}_{3}$ & 3.2 & 3.2 & 0.1 & 0.1 & 0.2 \\
\hline LoI & 4.2 & 2.5 & 30.1 & NA & NA \\
\hline $\mathrm{C}_{3} \mathrm{~S}$ & 50 & 53 & - & - & - \\
\hline $\mathrm{C}_{2} \mathrm{~S}$ & 12 & 16 & - & - & - \\
\hline $\mathrm{C}_{3} \mathrm{~A}$ & 4 & 10 & - & - & - \\
\hline $\mathrm{C}_{4} \mathrm{AF}$ & 15 & 7 & - & - & - \\
\hline $\mathrm{CaCO}_{3}$ & 4 & 3 & 61 & $<1$ & $<1$ \\
\hline
\end{tabular}

LoI: Lost of Ignition, NA: Not Analyzed 
TG/DTA tests, (4\% in CEM I 42.5 R-SR and 3\% in CEM I 42.5 R). The most notable difference between the two PCs is the alkali and $\mathrm{C}_{3} \mathrm{~A}$ contents. CEM I 42.5 R-SR had low alkali content $\left(0.4 \% \mathrm{Na}_{2} \mathrm{O}_{\text {eq. }}\right)$ while CEM I $42.5 \mathrm{R}$ had $0.7 \%$. The $\mathrm{C}_{3} \mathrm{~A}$ content was estimated through Bogue equations (27), after correction taking into account $\mathrm{CaCO}_{3}$ content, the obtained values were $4 \%$ for R-SR and $10 \%$ for R CEM I. The $\mathrm{C}_{4} \mathrm{AF}$ of both $\mathrm{PC}$ was also different, $15 \%$ for CEM I R-SR and 7\% in CEM I R. To differentiate both $\mathrm{PCs}, \mathrm{PC}_{\mathrm{L}}$ and $\mathrm{PC}_{\mathrm{H}}$ nomenclatures are used, where $\mathrm{L}$ indicates low alkali and low $\mathrm{C}_{3} \mathrm{~A}$ contents (PC CEM I R-SR) and $\mathrm{H}$ higher alkali and $\mathrm{C}_{3} \mathrm{~A}$ contents (PC CEM I R).

The chemical compositions of the mineral additions employed to prepare the mixes are also included in Table 1. All of them are commercial products. LF containing $61 \% \mathrm{CaCO}_{3}$ was used. The low content of the carbonates in the LF is due to the geological nature of the base rock (black limestone) used. FA with low calcium content and BFS were also employed as mineral additions for ternary binders. The three mineral additions had higher alkali and $\mathrm{Al}_{2} \mathrm{O}_{3}$ and lower $\mathrm{SO}_{3}$ contents than the PCs.

Binary and ternary blends were prepared using $\mathrm{PC}_{\mathrm{L}}$ or $\mathrm{PC}_{\mathrm{H}}$ plus one or two mineral additions, combining BFS, FA and LF in different proportions, as shown in Table 2. Both PCs were mixed in 100, 94 and $64 \%$ content. The content of BFS was varied from 26 to $36 \mathrm{wt} . \%, 10 \mathrm{wt} . \%$ for the FA and $6 \mathrm{wt} . \%$ for the LF. Additionally mixes with $36 \%$ of quartz $(\mathrm{Q})$ as inert addition were prepared. $\mathrm{PC}_{\mathrm{L}} 30 \mathrm{BFS6LF}$ and $\mathrm{PC}_{\mathrm{H}} 30 \mathrm{BFS6LF}$ are classified as CEM II/C-M (S-L) according to the new cement standard EN 197-1 (9). PC $_{\mathrm{L}}$ 26BFS10FA and $\mathrm{PC}_{\mathrm{H}}$ 26BFS10FA are classified as CEM II/C-M (S-V) according to the same standard. These ternary binders have been chosen in accordance with new EN 197-1 (9) and the experience from literature review $(11,15,24)$, and binary ones have been chosen to be compared with the ternary binders with BFS and LF.

Table 3 summarizes the particle size distribution of the raw materials with the mean size value and some percentiles. The mean particle sizes and the particle size distribution of $\mathrm{PC}_{\mathrm{L}}$ and $\mathrm{PC}_{\mathrm{H}}$ were similar. Thus, the differences between the two types of PC can be only related to their chemical and mineralogical compositions; BFS also shows similar particle size as the PCs. The highest particle size is observed for the FA and the lowest for the LF.

Cement pastes using a w/b ratio 0.5 were prepared. Setting time was determined with a Vicat needle,

TABLE 2. Composition (in $\%$ by weight) of blended mixes

\begin{tabular}{|c|c|c|c|c|c|c|}
\hline \multirow[b]{2}{*}{ Sample identification } & \multicolumn{6}{|c|}{$\%$} \\
\hline & $\mathrm{PC}_{\mathrm{L}}$ & $\mathbf{P C}_{\mathrm{H}}$ & BFS & FA & $\mathbf{L F}$ & $\mathbf{Q}$ \\
\hline $\mathrm{PC}_{\mathrm{L}}$ & 100 & - & - & - & - & - \\
\hline $\mathbf{P C}_{\mathrm{H}}$ & - & 100 & - & - & - & - \\
\hline $\mathrm{PC}_{\mathrm{L}} 6 \mathrm{LF}$ & 94 & - & - & - & 6 & - \\
\hline $\mathrm{PC}_{\mathrm{H}} 6 \mathrm{LF}$ & - & 94 & - & - & 6 & - \\
\hline $\mathrm{PC}_{\mathrm{L}}$ 36BFS & 64 & - & 36 & - & - & - \\
\hline $\mathrm{PC}_{\mathrm{H}} 36 \mathrm{BFS}$ & - & 64 & 36 & - & - & - \\
\hline$P_{L} 36 Q$ & 64 & - & - & - & - & 36 \\
\hline$P_{\mathrm{H}} 36 \mathrm{Q}$ & - & 64 & - & - & - & 36 \\
\hline $\mathrm{PC}_{\mathrm{L}}$ 30BFS6LF & 64 & - & 30 & - & 6 & - \\
\hline $\mathrm{PC}_{\mathrm{H}}$ 30BFS6LF & - & 64 & 30 & - & 6 & - \\
\hline $\mathrm{PC}_{\mathrm{L}}$ 26BFS10FA & 64 & - & 26 & 10 & - & - \\
\hline $\mathrm{PC}_{\mathrm{H}}$ 26BFS10FA & - & 64 & 26 & 10 & - & - \\
\hline
\end{tabular}

TABLE 3. Particle size distribution of the raw materials

\begin{tabular}{llcccc}
\hline & & $\mathbf{1 0} \%$ & $\mathbf{5 0} \%$ & $\mathbf{9 0} \%$ & Diameter Mean Size $(\boldsymbol{\mu m})$ \\
\hline Particle & $\mathbf{P C}_{\mathbf{L}}$ & 1.9 & 14.4 & 44.5 & 19.2 \\
& $\mathbf{P C}_{\mathbf{H}}$ & 1.8 & 13.4 & 41.3 & 17.8 \\
& $\mathbf{B F S}$ & 1.6 & 11.9 & 38.9 & 16.4 \\
& FA & 3.8 & 20.0 & 99.3 & 37.6 \\
& LF & 1.1 & 5.5 & 23.0 & 9.5 \\
\hline
\end{tabular}


following recommendations of EN 196-3 standard. All tests were performed at constant temperature using a thermostatic bath at $25^{\circ} \mathrm{C}$ for immersion of the cement paste mix during setting test.

Calorimetry tests were performed for both PCs, in binary and in ternary mixes to evaluate the initial contribution of the mineral additions, also PC incorporating 36\% quartz was evaluated in this case. For calorimetry tests a Thermometric TAM AIR calorimeter was used. The samples were prepared with 6 grams of binder and 3 grams of water. The tests lasted 7 days at $20^{\circ} \mathrm{C}$. The pastes were introduced in the calorimeter immediately after being mixed and shaken during 60 seconds.

Mortars were prepared to study mechanical and porosity changes. $4 \times 4 \times 16 \mathrm{~cm}$ prismatic samples were fabricated with a w/b $=0.5$ and binder/sand $=1 / 3$. These samples were demolded after 24 hours and kept in a curing chamber at $21 \pm 2{ }^{\circ} \mathrm{C}$ and $98 \pm 2 \%$ $\mathrm{RH}$ until testing. The evolution of the mechanical and the pore size properties of the mortars were determined after 1, 7, 28 and 90 days of hydration. The mechanical strength results refer to mean values of two and four measurements of flexural and compressive strength, respectively.

The pore size distribution and total porosity values were also obtained using mercury intrusion porosimetry at 1, 7, 28 and 90 days of hydration. A piece of mortar with approximately $1 \mathrm{~cm}^{3}$ was used $(2.5$ times higher than the maximum particle size of the sand) in order to guarantee the representativeness of the sample. This piece was obtained from the core of an additional prismatic sample. The hydration process was then stopped at each specific curing age by removing the free water with ethanol and acetone.

\section{RESULTS AND DISCUSSION}

\subsection{Ternary blends contribution to the early cement hydration}

The incorporation of mineral additions changes the early hydration, as also found by other authors (28-31). One of the properties modified is the setting time. Table 4 compares the initial and final setting times of the binary and ternary blends, and the reference samples $\left(\mathrm{PC}_{\mathrm{L}}\right.$ and $\left.\mathrm{PC}_{\mathrm{H}}\right)$.

The chemical composition of the plain PC clearly affects the setting time. $\mathrm{PC}_{\mathrm{H}}$ showed initial setting after 1.7 hours while $\mathrm{PC}_{\mathrm{L}}$ set only after 3.3 hours. In this sense, setting time depends on the initial particle size (which is similar for the two cements) and the composition of the binders $(32,33) . \mathrm{PC}_{\mathrm{H}}$ had some higher content of alite and aluminate than $\mathrm{PC}_{\mathrm{L}}$ consistent with the faster setting of $\mathrm{PC}_{\mathrm{H}}$. The higher initial content of alkalis in $\mathrm{PC}_{\mathrm{H}}$ contributed to accelerate the setting too, as also found in (16).

The incorporation of $36 \%$ BFS retarded the setting times compared to $\mathrm{PC}_{\mathrm{L}}$ by $18 \%$, in accordance with $(34,35)$. However, with ternary blends the retardation in setting caused by the introduction of BFS was significantly reduced with the incorporation of LF (12\%). Different causes can be contributing to this fact, the LF at early ages favors higher effective water/PC ratio for reaction and provides additional sites for the nucleation of hydration products $(30,31)$. Besides, the BFS also contributes to accelerate the clinker hydration (19), but its role depends on the PC composition as found in (21). In fact, higher portlandite content was detected at early ages of hydration with $\mathrm{PC}_{\mathrm{L}} 30 \mathrm{BFS6LF}$ but lower content in $\mathrm{Al}$ and $\mathrm{Si}$ in the pore solution with respect to $\mathrm{PC}_{\mathrm{H}} 30 \mathrm{BFS6LF}$. These phenomena can explain the differences in initial reactivity of anhydrous phases in both PCs in presence of synergic mineral additions.

Similar trends are observed for ternary blends containing $\mathrm{BFS}+\mathrm{FA}$; the relative delay in setting was again more significant for $\mathrm{PC}_{\mathrm{H}}$, although the absolute setting times were shorter for $\mathrm{PC}_{\mathrm{H}}$. The presence of FA resulted in later setting than in the presence of LF. These results agree with the higher setting times reported for ternary blends formed by PC with low alkali content, FA and LF, with respect to the setting times obtained in binary blends without LF (20).

The delay observed in setting time in the presence of mineral additions should be closely related to the heat flow measured by calorimetry. Figures 1 and 2 show the heat flow measured for PCs and the blends

TABLE 4. Initial and final setting times

\begin{tabular}{lcccc}
\hline Samples Identification & $\begin{array}{c}\text { Initial setting } \\
\text { (h) }\end{array}$ & $\begin{array}{c}\text { \% } \Delta \text { delay } \\
\text { relative to PC }\end{array}$ & $\begin{array}{c}\text { Final Setting } \\
\text { (h) }\end{array}$ & $\begin{array}{c}\text { \% } \Delta \text { delay } \\
\text { relative to PC }\end{array}$ \\
\hline PC $_{\mathbf{L}}$ & 3.3 & - & 4.3 & - \\
PC $_{\mathbf{H}}$ & 1.7 & - & 2.4 & - \\
PC $_{\mathbf{L}}$ 36BFS & 3.9 & 18 & 5.2 & 21 \\
PC $_{\mathbf{L}}$ 30BFS6LF & 3.7 & 12 & 4.8 & 12 \\
PC $_{\mathbf{H}}$ 30BFS6LF & 2.0 & 18 & 2.8 & 17 \\
PC $_{\mathbf{L}}$ 26BFS10FA & 4.0 & 21 & 4.9 & 14 \\
PC $_{\mathbf{H}}$ 26BFS10FA & 2.2 & 29 & 3.2 & 33 \\
\hline
\end{tabular}


during the first 50 hours of hydration. Heat flow results were normalized to $100 \%$ of $\mathrm{PC}$ in order to allow comparison and facilitate the detection of the contribution of the mineral additions on the cement hydration.

All mixes showed a very early reaction (dissolution), the initial period (I) followed by an induction period (II), with a low heat flow during first hours. The length of induction period varied with the type of PC used to prepare the blend, but is only very little affected by the presence of mineral additions. This indicates that the early reaction was dominated by $\mathrm{PC}$ due to the $\mathrm{C}_{3} \mathrm{~S}$ dissolution and hydration and the formation of C-S-H and portlandite as noticed in (36-38), which caused a sharp increase in heat flow after the induction period, the acceleration period (III). The onset of period III was faster for $\mathrm{PC}_{\mathrm{H}}$ than for $\mathrm{PC}_{\mathrm{L}}$, and the heat flow per gram of $\mathrm{PC}$ at the maximum of the exothermic heat peak was higher in the presence of the mineral additions. This fact can be related to the higher effective water to $\mathrm{PC}$ ratio of the ternary mixes during the initial hydration. As no or little of quartz, BFS, FA or LF reacted during the first hours of mixed, more water was available per $\mathrm{g}$ of Portland cement, which leaded to a faster reaction of the $\mathrm{PC}$ as also found in (31). Generally setting took place within this period. A shoulder at around 20 hours for $\mathrm{PC}_{\mathrm{L}}$ and 15 hours for $\mathrm{PC}_{\mathrm{H}}$ was observed. Minerals additions had little effect on the appearance of the first shoulder. This shoulder has been attributed to the heat released in the $\mathrm{C}_{3} \mathrm{~A}$ dissolution and the precipitation of ettringite (38) from the PC that had been also identified by XRD in similar ternary mixes after 2 days of hydration (21).

A second shoulder between 25 to 35 hours was clearly observed in blends containing $\mathrm{PC}_{\mathrm{H}}$. Its appearance and duration depended on the mineral addition employed as can be seen in Figure 1-right and Figure 2. This shoulder was not clear in $\mathrm{PC}_{\mathrm{L}}$ mixes, but it had been observed in blends based on
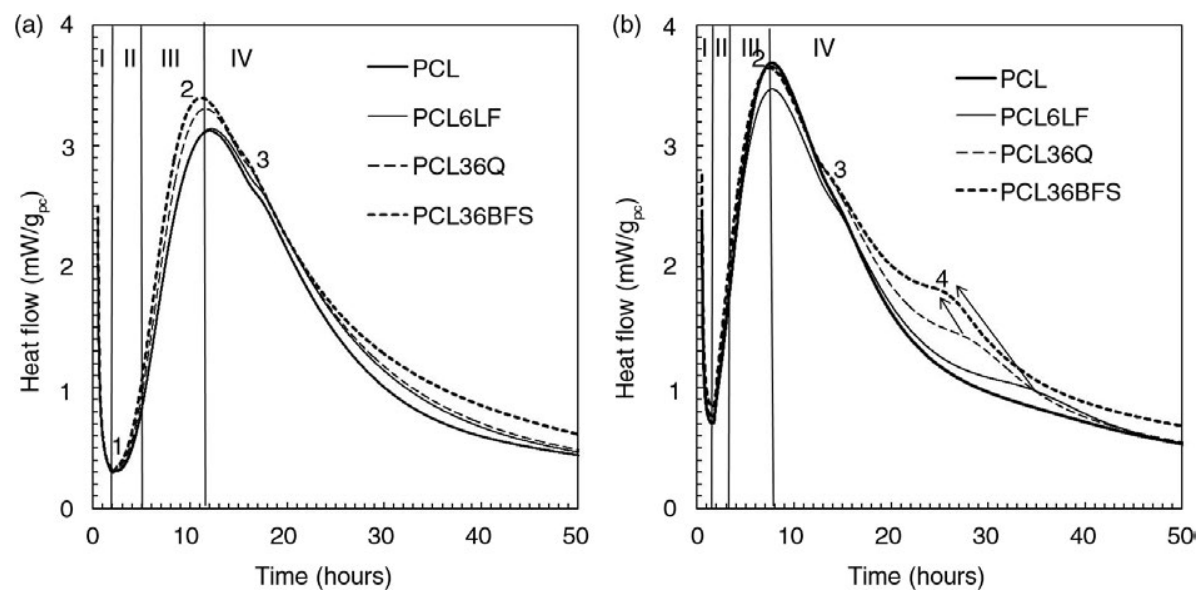

Figure 1. Heat flow per gram of $\mathrm{PC}$ during the first 50 hours of hydration. Left) $\mathrm{PC}_{\mathrm{L}}$ and binary blends based on $\mathrm{PC}_{\mathrm{L}}$. Right) $\mathrm{PC}_{\mathrm{H}}$ and binary blends based on $\mathrm{PC}_{\mathrm{H}}$.
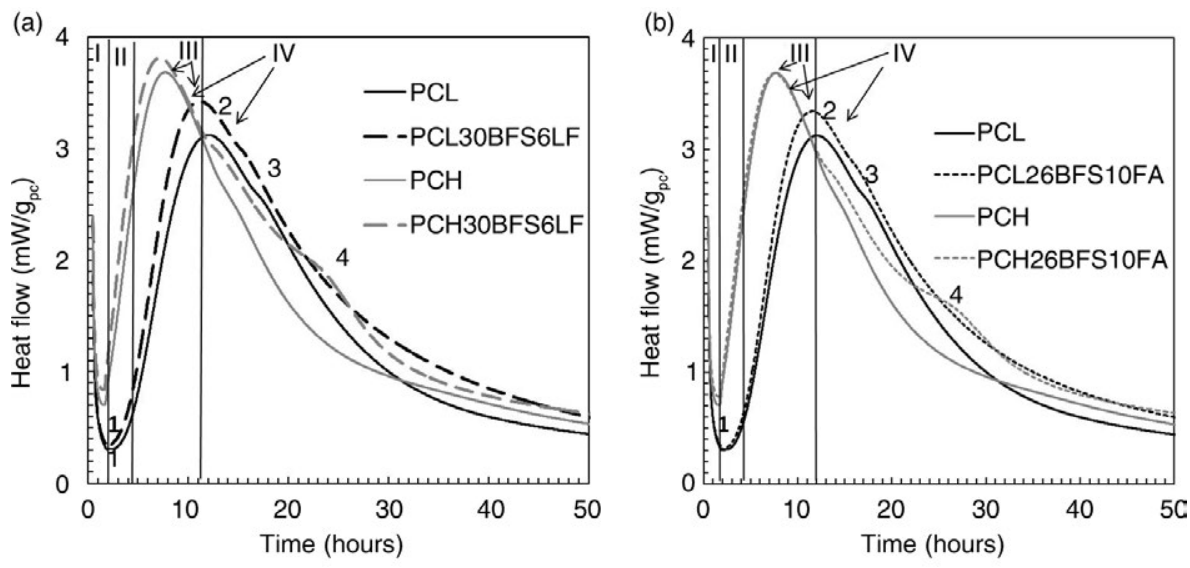

FIgURE 2. Heat flow per gram of $\mathrm{PC}$ during the first 50 hours of hydration. Left) $\mathrm{PC}_{\mathrm{L}}$ and $\mathrm{PC}_{\mathrm{H}}$ and ternary blends with $30 \mathrm{BFS}+6 \mathrm{LF}$. Right) $\mathrm{PC}_{\mathrm{L}}$ and $\mathrm{PC}_{\mathrm{H}}$ and ternary blends with $26 \% \mathrm{BFS}+10 \% \mathrm{FA}$. 
PC with low alkali content and high replacement of BFS (39). The second shoulder had been attributed to a faster reaction of the $\mathrm{C}_{4} \mathrm{AF}$ from the $\mathrm{PC}$ in blends containing BFS (19). In present case, the $\mathrm{C}_{4} \mathrm{AF}$ content in $\mathrm{PC}_{\mathrm{L}}$ was higher $(15 \%)$ than in $\mathrm{PC}_{\mathrm{H}}$ $(7 \%)$; however, other factors as the higher $\mathrm{pH}$ in $\mathrm{PC}_{\mathrm{H}}$ can influence the intensity of the shoulder in the ternary binders with this PC.

The two shoulders appeared in the last period (retardation period: IV) of hydration, which was a progressive deceleration resulting in a continuous decrease of heat flow. Table 5 summarizes the time period and the heat flow associated to each binder composition in the singular points (1-4) identified in Figures 1 and 2.

The influence and differences with the PC type can be clearly identified. $\mathrm{PC}_{\mathrm{L}}$ mixes showed a similar exothermic heat flow in $\mathrm{T} 1$ but lower than $\mathrm{PC}_{\mathrm{H}}$ mixes. In fact, $\mathrm{PC}_{\mathrm{H}}$ mixes with mineral additions showed a certain increase in this parameter. In period T2 the maximum of the heat flow was more similar for binders using the two PC, although some higher with $\mathrm{PC}_{\mathrm{H}}$, what justifies the higher activity at early hydration with $\mathrm{PC}_{\mathrm{H}}$. At longer time, in period
T3 the response was very similar whatever the type of PC, but clear differences were observed again at period T4 in $\mathrm{PC}_{\mathrm{H}}$ showing higher heat flow.

After 24 hours of hydration, the formation of a rigid and hardened cement paste is obtained. The physical-mechanical properties at 24 hours in mortar still reflect the history of processes occurring during the first hours of hydration. Thus, the mortars showed differences in total porosity, average pore diameter, pore structure and mechanical strength as compiled in Table 6 and Figures 3 and 4.

There were several differences in pore size structure between the mixes depending on the PC composition. The $\mathrm{PC}_{\mathrm{H}}$ showed a more refined pore structure in all mixes, especially in the region of small pores $(<1 \mu \mathrm{m})$, probably due to a higher degree of reaction as observed in the higher heat flow (Figure 2, Table 5). The total porosity of the mixes with $\mathrm{PC}_{\mathrm{H}}$ was also lower (Table 6). In agreement with the slower reaction of $\mathrm{PC}_{\mathrm{L}}$, bigger pores were observed except for $\mathrm{PC}_{\mathrm{L}} 30 \mathrm{BFS6LF}$. PC $\mathrm{L}_{\mathrm{L}}$ 30BFS6LF blend had a clearly refined pore structure, particularly fewer capillary pores (1 to $10 \mu \mathrm{m})$. The result of the refinement of $\mathrm{PC}_{\mathrm{L}} 30 \mathrm{BFS6LF}$ explains its good

TABLE 5. Time period (T) and corresponding heat flow (HF) in function of binder composition

\begin{tabular}{lcccccccc}
\hline $\begin{array}{l}\text { Samples } \\
\text { Identification }\end{array}$ & T 1 (h) & $\begin{array}{c}\text { HF 1 } \\
(\mathbf{m W / g P C})\end{array}$ & T 2 (h) & $\begin{array}{c}\text { HF 2 } \\
(\mathbf{m W / g P C})\end{array}$ & T 3 (h) & $\begin{array}{c}\text { HF 3 } \\
\text { (mW/gPC) }\end{array}$ & $\begin{array}{c}\text { T 4 (h) } \\
\text { (mW/gPC) }\end{array}$ \\
\hline PC $_{\mathbf{L}}$ & 1.9 & 0.3 & 12.0 & 3.1 & 16.7 & 2.6 & - & - \\
PC $_{\mathbf{L}}$ 6LF & 2.1 & 0.3 & 12.1 & 3.1 & 17.0 & 2.6 & - & - \\
PC $_{\mathbf{L}}$ 36Q & 2.1 & 0.3 & 11.6 & 3.6 & 15.7 & 2.9 & - & - \\
PC $_{\mathbf{L}}$ 36BFS & 2.1 & 0.3 & 11.2 & 3.4 & 15.1 & 3.0 & - & - \\
PC $_{\mathbf{L}}$ 30BFS6LF & 2.1 & 0.3 & 11.2 & 3.4 & 15.1 & 3.0 & - & - \\
PC $_{\mathbf{L}}$ 26BFS10FA & 2.2 & 0.3 & 11.5 & 3.3 & 15.3 & 2.9 & - & - \\
PC $_{\mathbf{H}}$ & 1.5 & 0.7 & 7.7 & 3.7 & 13.6 & 2.7 & - & - \\
PC $_{\mathbf{H}}$ 6LF & 1.7 & 0.8 & 7.7 & 3.5 & 14.0 & 2.5 & 34.0 & 1.0 \\
PC $_{\mathbf{H}}$ 36Q & 1.6 & 0.7 & 7.6 & 3.7 & 13.6 & 2.7 & 27.5 & 1.4 \\
PC $_{\mathbf{H}}$ 36BFS & 1.5 & 0.8 & 7.5 & 3.6 & 13.7 & 2.7 & 24.8 & 1.8 \\
PC $_{\mathbf{H}}$ 30BFS6LF & 1.6 & 0.8 & 7.2 & 3.8 & 12.3 & 3.0 & 21.6 & 2.0 \\
PC $_{\mathbf{H}}$ 26BFS10FA & 1.5 & 0.8 & 7.6 & 3.7 & 13.3 & 2.8 & 24.5 & 1.7 \\
\hline
\end{tabular}

TABLE 6. Total porosity and average pore diameter at 24 hours of hydration of PCs, binary and ternary blends

\begin{tabular}{|c|c|c|c|c|}
\hline \multicolumn{5}{|c|}{ Total Porosity $(\%) /$ Average Pore Diameter $(\mu \mathrm{m})$} \\
\hline Samples Identification & 1 day & 7 days & 28 days & 90 days \\
\hline $\mathbf{P C}_{\mathrm{L}}$ & $17.0 / 0.15$ & $13.7 / 0.12$ & $15.8 / 0.09$ & $15.3 / 0.07$ \\
\hline $\mathrm{PC}_{\mathrm{L}}$ 36BFS & $16.0 / 0.10$ & $12.0 / 0.07$ & $12.7 / 0.06$ & $9.8 / 0.07$ \\
\hline $\mathrm{PC}_{\mathrm{L}}$ 30BFS6LF & $15.8 / 0.09$ & $14.8 / 0.07$ & $12.0 / 0.04$ & $10.3 / 0.04$ \\
\hline PC $_{\mathrm{L}}$ 26BFS10FA & $14.9 / 0.08$ & $12.6 / 0.07$ & $11.3 / 0.05$ & $9.5 / 0.04$ \\
\hline $\mathbf{P C}_{\mathrm{H}}$ & $13.2 / 0.15$ & $13.0 / 0.18$ & $13.6 / 0.15$ & $12.3 / 0.13$ \\
\hline $\mathrm{PC}_{\mathrm{H}}$ 30BFS6LF & $12.9 / 0.08$ & $11.6 / 0.07$ & $9.9 / 0.06$ & $10.9 / 0.06$ \\
\hline PC $_{\mathrm{H}}$ 26BFS10FA & $14.4 / 0.10$ & 14.6/0.09 & $12.9 / 0.06$ & $14.6 / 0.07$ \\
\hline
\end{tabular}



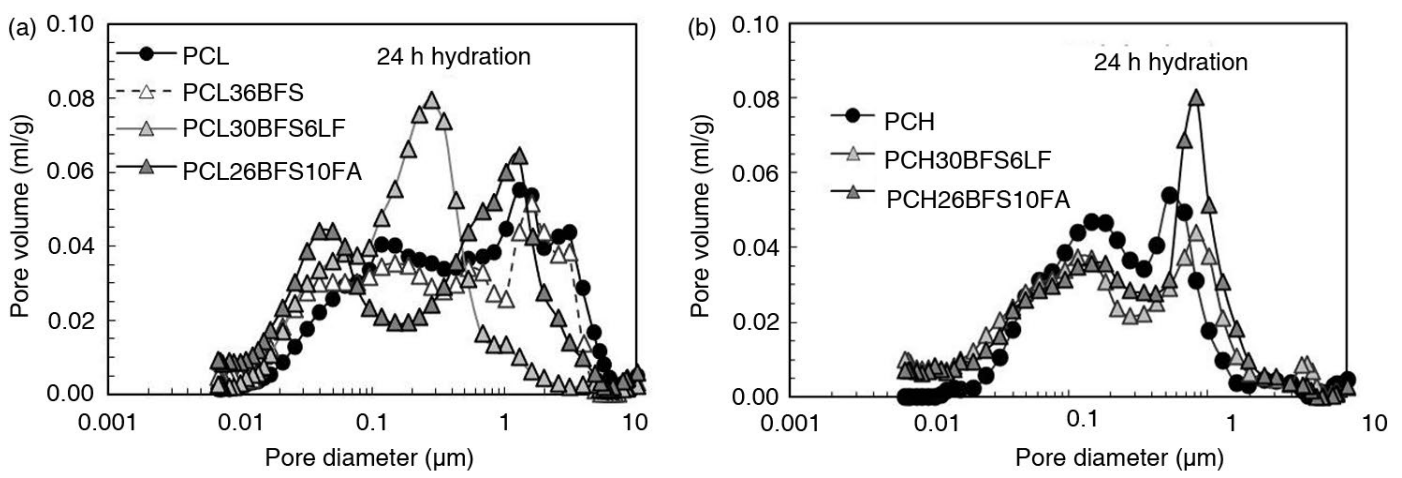

FIgURE 3. Pore size distribution at 24 hours of hydration of PCs, binary and ternary blends.

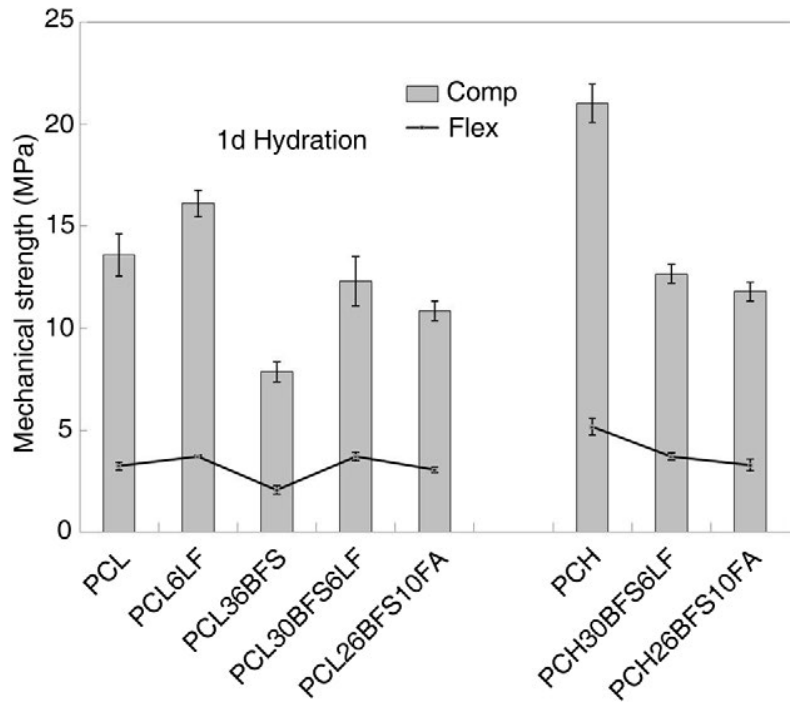

FIGURE 4. Mechanical properties at 24 hours of hydration of PCs, binary and ternary blends.

mechanical properties shown in Figure 4 in comparison to its reference without mineral additions.

The binary mix with BFS reached lower compressive strength than $\mathrm{PC}_{\mathrm{L}}$. While the ternary mixes with $\mathrm{PC}_{\mathrm{L}}$ and plain $\mathrm{PC}_{\mathrm{L}}$ mortar exhibited similar compressive strength, the incorporation of $\mathrm{LF}(6 \%)$ in a binary mix increased compressive strength. This is related to synergistic contribution of mineral addition with the PC type, in this case the lower particle size of LF and the good ability of limestone to act as nucleation sites for C-S-H accelerating the initial hydration of $\mathrm{PC}_{\mathrm{L}}$ must be contributing, as also suggested in $(30,31,40)$.

After 1 day of hydration, the $\mathrm{PC}_{\mathrm{H}}$ had higher mechanical strength than $\mathrm{PC}_{\mathrm{L}}$, in accordance with the setting times (Table 4) and calorimetric data (Figures 1 and 2). However, in contrast to $\mathrm{PC}_{\mathrm{L}}$, the ternary blends of $\mathrm{PC}_{\mathrm{H}}$ had much less strength than the plain $\mathrm{PC}_{\mathrm{H}}$. In $\mathrm{PC}_{\mathrm{L}} 30 \mathrm{BFS6} \mathrm{LF}$ mix the slower reaction of $\mathrm{BFS}$ than $\mathrm{PC}$ as suggested in (16) was compensated by the acceleration induced by the LF in accordance with (40). The beneficial effect in ternary blends with BFS and FA can be also associated with the acceleration of the initial clinker hydration as suggested in $(19,22,41)$, although this effect is expected to be less effective than for LF. In fact, in present study the compressive strength after 1 day of hydration was slightly lower in ternary binders with BFS + FA as also the setting time was slightly slower (Table 4).

In summary, ternary blends with $\mathrm{PC}_{\mathrm{L}}$ minimized the loss in mechanical properties at early hydration ages $(24 \mathrm{~h})$, while in blends with $\mathrm{PC}_{\mathrm{H}}$, which exhibited a higher initial hydration, the incorporation of combined mineral additions further decreased the compressive and flexural strength.

\subsection{Contribution of blends to the built-up of the microstructure and the mechanical properties}

After the early hydration ( $24 \mathrm{~h}$ ), which was dominated by the reaction of the Portland cement, the contribution of the mineral additions slowly became more important. The cumulative heat flow summarized in Table 7 shows a slightly higher total heat flow after two days in the presence of inert quartz, but no significant contribution of the quartz after this time. The slightly higher heat flow measured was related to the higher effective water to Portland cement ratio, which leaded to the availability of more water and thus a higher hydration degree of the Portland cement as also found in (31). The blends with LF showed some more heat flow after 48 hours in both cements, as a part of the LF could react with the aluminates to form monocarbonate thus preventing the destabilization of ettringite and it also accelerated the $\mathrm{PC}$ reactions $(5,22)$. The participation of BFS and FA was clearly observed after 48 hours, both in binary and ternary mixes. The contribution was more pronounced in the case of BFS, due to its higher hydraulic reactivity (16), while FA reacted slowly $(13,26,42)$. This explains the higher total heat flow of $\mathrm{PC}_{\mathrm{L} / \mathrm{H}} 30 \mathrm{BFS} 6 \mathrm{LF}$ than that of $\mathrm{PC}_{\mathrm{L} /}$ ${ }_{\mathrm{H}}$ 26BFS10FA. 
TABLE 7. Cumulative heat flow (HF) and relative increase as a function of mineral additions

\begin{tabular}{lcccccc}
\hline $\begin{array}{l}\text { Samples } \\
\text { Identification }\end{array}$ & $\begin{array}{c}\text { Cumulated } \\
\text { H-F 1d Hydr. } \\
\text { (mW/gPC) }\end{array}$ & $\begin{array}{c}\text { \% increase } \\
\text { relative to PC }\end{array}$ & $\begin{array}{c}\text { Cumulated } \\
\text { H-F 2d Hydr. } \\
\text { (mW/gPC) }\end{array}$ & $\begin{array}{c}\text { Cumulated } \\
\text { \% increase } \\
\text { relative to PC }\end{array}$ & $\begin{array}{c}\text { H-F 7d Hydr. } \\
\text { (mW/gPC) }\end{array}$ & $\begin{array}{c}\text { \% increase } \\
\text { relative to PC }\end{array}$ \\
\hline PC $_{\mathbf{L}}$ & 170 & - & 239 & - & 314 & - \\
PC $_{\mathbf{L}}$ 36Q & 174 & 2 & 252 & 5 & 328 & 4 \\
PC $_{\mathbf{L}}$ 6LF & 181 & 7 & 262 & 9 & 340 & 8 \\
PC $_{\mathbf{L}}$ 36BFS & 187 & 10 & 278 & 16 & 392 & 25 \\
PC $_{\mathbf{L}}$ 30BFS6LF & 189 & 11 & 281 & 17 & 392 & 25 \\
PC $_{\mathbf{L}}$ 26BFS10FA & 183 & 8 & 273 & 14 & 379 & 21 \\
PC $_{\mathbf{H}}$ & 197 & - & 268 & - & 357 & - \\
PC $_{\mathbf{H}}$ 36Q & 194 & 0 & 272 & 2 & 367 & 3 \\
PC $_{\mathbf{H}}$ 6LF & 206 & 5 & 291 & 9 & 385 & 8 \\
PC $_{\mathbf{H}}$ 36BFS & 213 & 8 & 310 & 16 & 449 & 26 \\
PC $_{\mathbf{H}}$ 30BFS6LF & 223 & 14 & 309 & 15 & 439 & 23 \\
PC $_{\mathbf{H}}$ 26BFS10FA & 211 & 7 & 300 & 12 & 427 & 20 \\
\hline
\end{tabular}
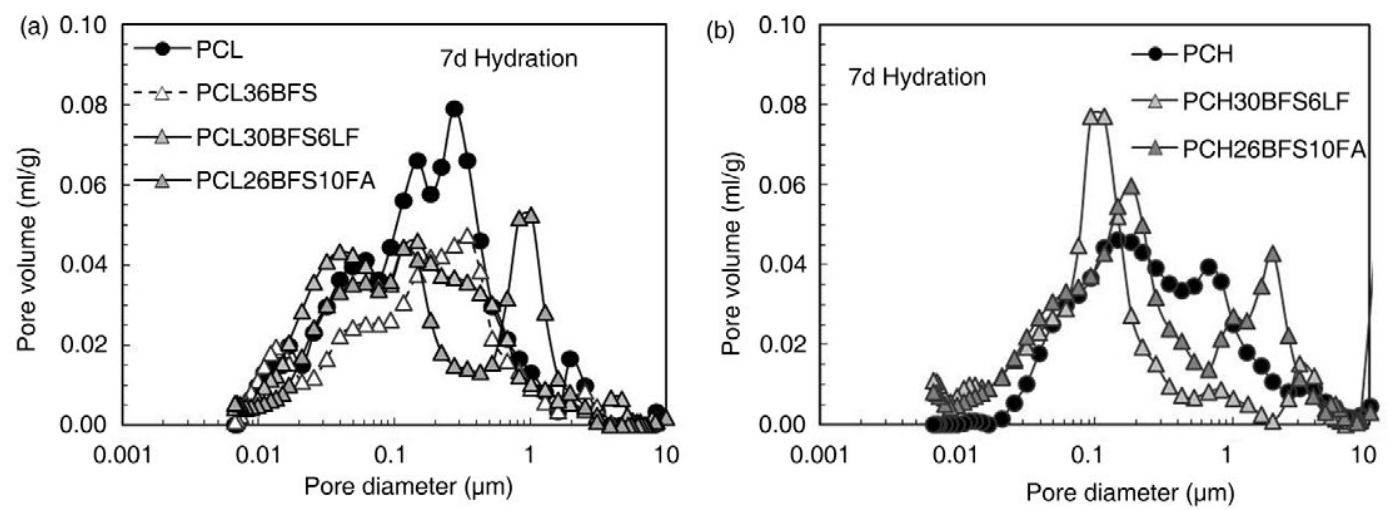

FIgURE 5. Pore size distribution at 7 days of hydration of PCs, binary and ternary blends.
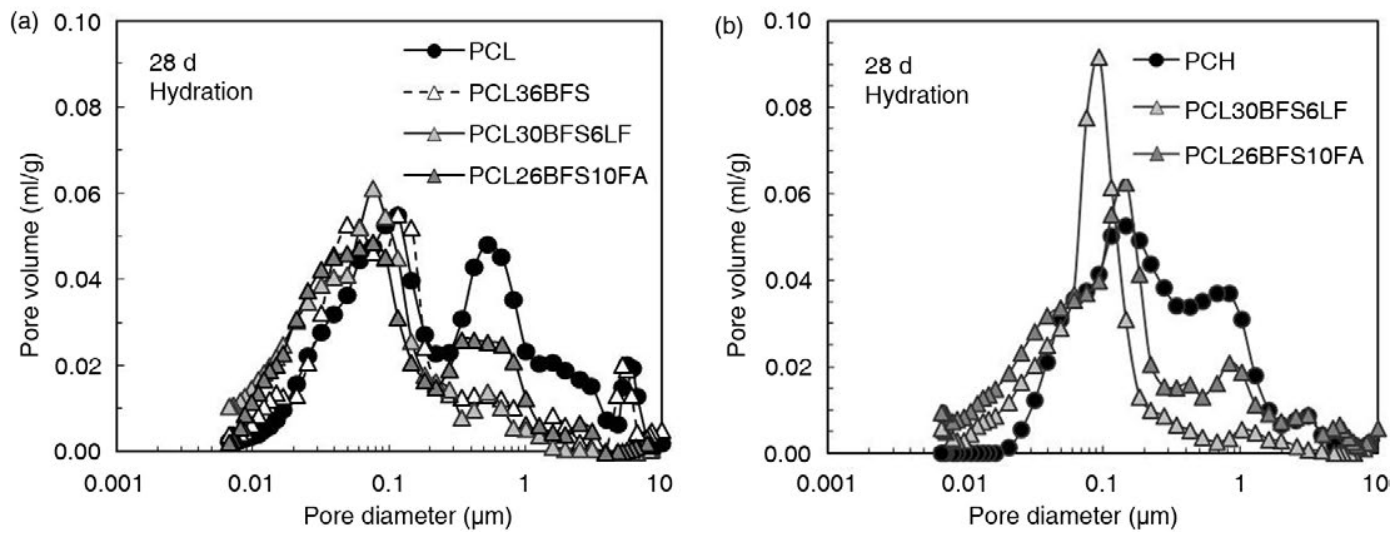

Figure 6. Pore size evolution at 28 days of hydration of PCs, binary and ternary blends.

The porosity or rather fraction of space occupied by unreacted solids and hydrates determines the mechanical properties for the mortars. Thus a refinement of the pore structure is expected to increase mechanical strength. Mineral additions refined significantly the pore structure compared to the plain PCs and also reduced the total porosity, especially in blends based on $\mathrm{PC}_{\mathrm{L}}$ after 90 days of 

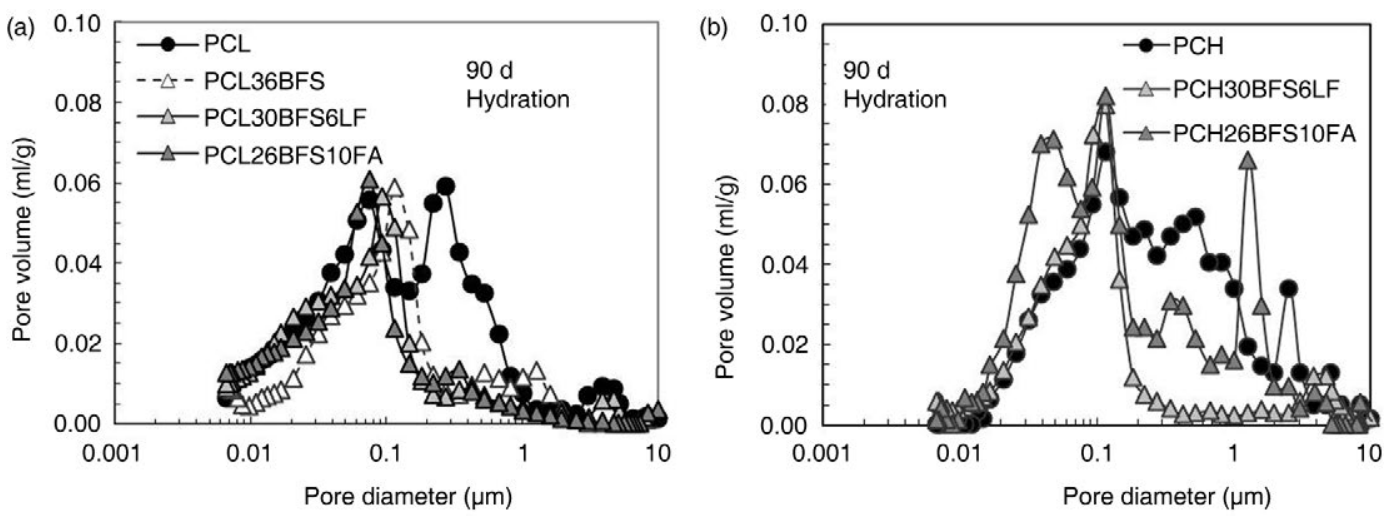

FIgURE 7. Pore size evolution at 90 days of hydration of PCs, binary and ternary blends.

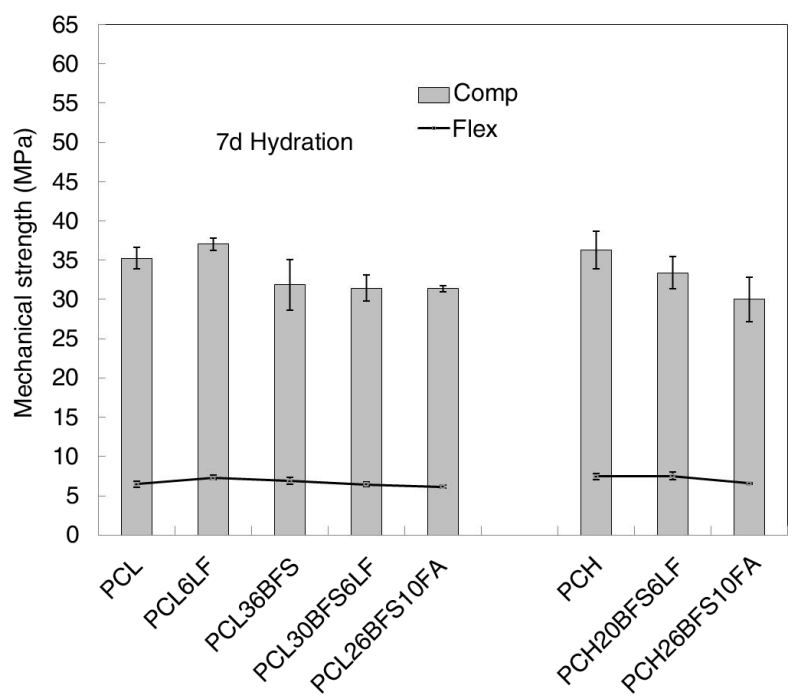

Figure 8. Mechanical properties at 7 days of hydration of PCs, binary and ternary blends.

hydration. Figures 5 to 7 compile the pore size distribution and the Table 6 shows the total porosity at 7,28 and 90 days of hydration.

The contribution of the hydration of FA and in particular of BFS, as observed from heat flow, was mirrored in the refined pore structure both for binary and ternary blends. The refinement of the pores was less distinct in ternary blends containing FA due to its lower reactivity. This refinement of the pores was in agreement with the higher bound water content of BFS + LF compared to BFS + FA ternary blends observed in the first week of hydration as found in a previous work (21). In all cases, the blends showed fewer capillary pores at 90 days of hydration than the plain $\mathrm{PC}_{\mathrm{L}}$

In summary, regardless of the type of $\mathrm{PC}$ and additions combined, the inclusion of a mix of BFS and FA or limestone up to $36 \%$ refined the pore microstructure. In addition, it did not penalize the mechanical strength compared to plain PC after 28 days and longer (Figures 8-10).

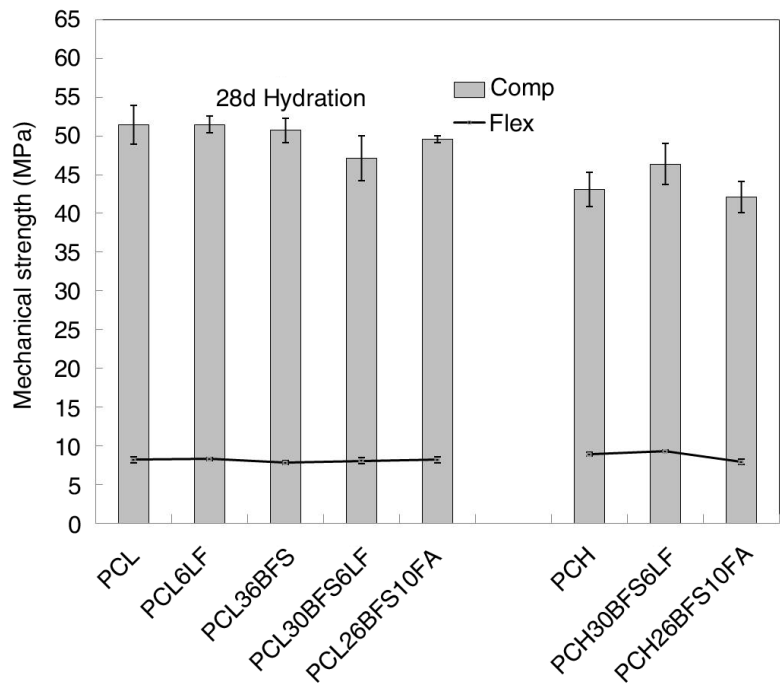

FIGURE 9. Mechanical properties at 28 days of hydration of PCs, binary and ternary blends.

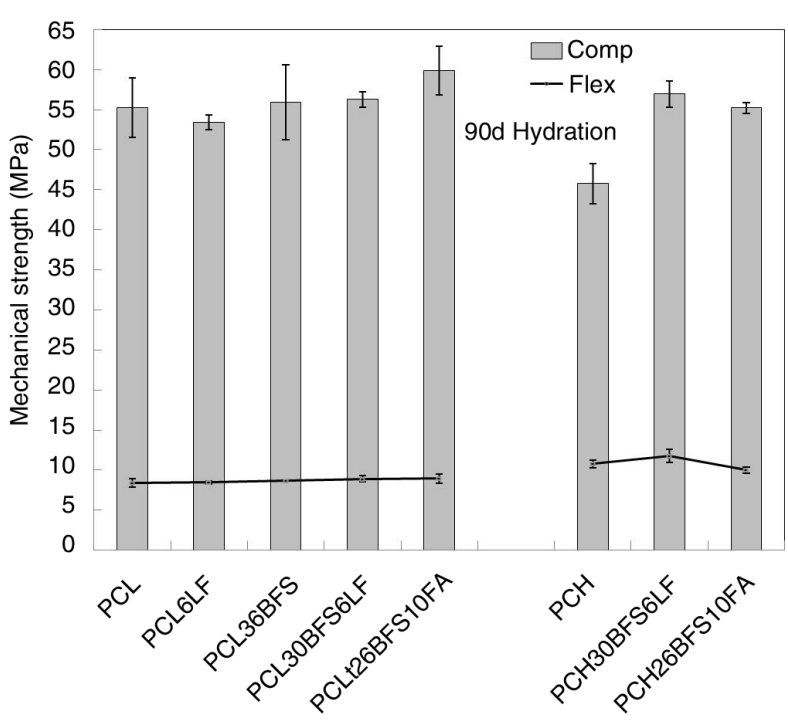

FIGURE 10. Mechanical properties at 90 days of hydration of PCs, binary and ternary blends. 

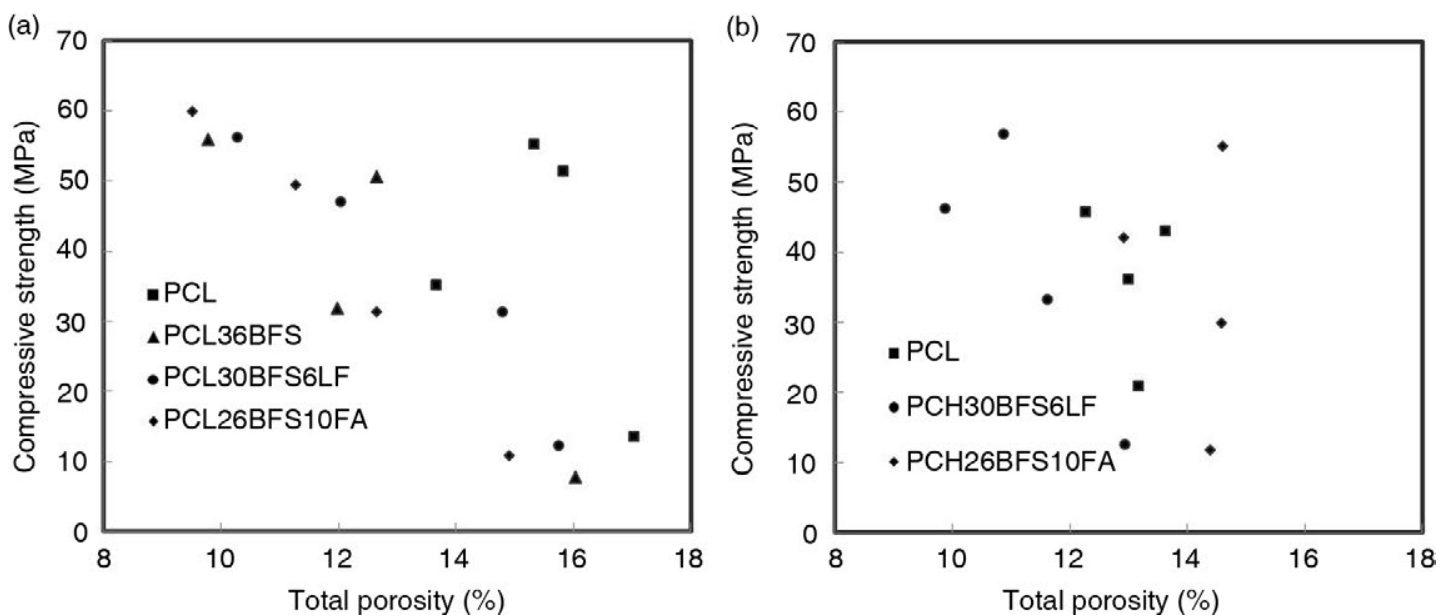

Figure 11. Compressive strength against porosity at 1, 7,28 and 90 days of hydration of PCs, binary and ternary blends.

After 90 days of hydration the $\mathrm{PC}_{\mathrm{L}} 26 \mathrm{BFS} 10 \mathrm{FA}$ blend had a somewhat higher compressive strength than $\mathrm{PC}_{\mathrm{L}} 30 \mathrm{BFS6LF}$ as consequence of the pozzolanic reactions of the FA. Although FA reacted slower than the clinker (43) or BFS (13), its reaction could generate additional hydration products and thus a higher compressive strength after long hydration times. In fact, only 20 to $25 \%$ of FA will have reacted in such blends (44-46) after 90 days of hydration. It is remarkable that there were not significant differences in the compressive strength between the same blends with different PC. However, the values of $\mathrm{PC}_{\mathrm{L}}$ 26BFS10FA were higher than $\mathrm{PC}_{\mathrm{H}}$ 26BFS10FA, indicating that the reactivity of the FA varies with the type of PC. For the plain $\mathrm{PC}_{\mathrm{H}}$, which had shown a fast initial hydration and high early strength, slight refinement of the pore structure and slight increase of compressive strength was observed after 28 days, such that after 90 days $\mathrm{PC}_{\mathrm{H}}$ had the lowest compressive strength of the evaluated samples. This also agrees with the increase in the bound water content measured after 28 days detected in ternary blends (based on both $\mathrm{PCs}$ ) and $\mathrm{PC}_{\mathrm{L}}$ pastes but not in $\mathrm{PC}_{\mathrm{H}}$ one (21).

This mechanical response correlates with the porosity. In fact, a good correlation between the compressive strength and the total porosity was found, especially in ternary blends based on $\mathrm{PC}_{\mathrm{L}}$, as can be seen in Figure 11.

In general, samples based on $\mathrm{PC}_{\mathrm{L}}$ had a better correlation between both parameters, especially the blends. In this sense, the $\mathrm{PC}_{\mathrm{L}}$ sample at 28 and 90 days of hydration had higher total porosity values than expected considering the compressive strength values. By contrast, the results of the samples based on $\mathrm{PC}_{\mathrm{H}}$ had more dispersion. These results also agree with the loss of effectiveness of the mineral additions when they were used with $\mathrm{PC}_{\mathrm{H}}$, mainly in the early ages.

\section{CONCLUSIONS}

The chemical and mineralogical composition of the $\mathrm{PC}$ is a key parameter in the hydration kinetics and in the synergy between $P C$ and mineral additions.

- Low alkali and low $\mathrm{C}_{3} \mathrm{~A}$ Portland $\left(\mathrm{PC}_{\mathrm{L}}\right)$ cement exhibit a slower hydration initiation, that results in later setting time, lower initial heat flow, lower early strength generation and less pore structure refinement than higher alkali and higher $\mathrm{C}_{3} \mathrm{~A}$ content cement $\left(\mathrm{PC}_{\mathrm{H}}\right)$. However, in the long term, $\mathrm{PC}_{\mathrm{L}}$ has a more refined pore structure and a higher compressive strength than $\mathrm{PC}_{\mathrm{H}}$.

- The PC type used in ternary blends influences the generation of properties at early ages of hydration. At long hydration times, however, higher compressive strengths were observed in all ternary blends regardless the PC type.

- For higher alkali and higher $\mathrm{C}_{3} \mathrm{~A}$ cement $\left(\mathrm{PC}_{\mathrm{H}}\right)$, the blending with two mineral additions (in the contents and compositions evaluated in this paper) significantly reduces the initial heat flow of the hydration, delays the setting, causes poorer initial mechanical strength and coarser pore structure with respect to the reference PC without additions. In the long term, however, the reaction of the mineral additions results in a more refined pore structure and higher compressive strength of the ternary blends studied than that of plain $\mathrm{PC}_{\mathrm{H}}$.

- For low alkali and low $\mathrm{C}_{3} \mathrm{~A}$ cement $\left(\mathrm{PC}_{\mathrm{L}}\right)$, the presence of mineral additions had little delay in the initial heat flow and setting times, resulting in similar early mechanical strength and porosity than for plain PC. These good mechanical properties of the ternary blends are maintained and even improved at longer ages of hydration, also in the pore structure refinement.

- Ternary blends containing FA show significant dependence of the PC composition used. 


\section{ACKNOWLEDGMENTS}

Authors gratefully acknowledge the Spanish MICINN for the financial support given to this research in BIA2011-22760 project. The authors are also grateful to Frank Winnefeld for the help with the calorimetric measurements and to "Cementos Portland Valderrivas", "Sociedad Anónima Tudela Veguín" and "Canteras El Cerro" for supply the raw materials used in this study.

\section{REFERENCES}

1. The European Cement Association. http://www.cembureau.be/sites/default/files/World $\% 20$ Cement $\% 20$ production_2.pdf

2. Schneider, M.; Romer, M.; Tschudin, M.; Bolio, H. (2011) Sustainable cement production-present and future. Cem. Concr: Res. 41, 642-650. http://dx.doi.org/10.1016/j. cemconres.2011.03.019

3. Damtoft, J.S.; Lukasik, J.; Herfort, D.; Sorrentino, D.; Gartner, E.M. (2008) Sustainable development and climate change initiatives. Cem. Concr. Res. 38, 115-127. http:// dx.doi.org/10.1016/j.cemconres.2007.09.008.

4. Deja, J.; Uliasz-Bochencyzk, A.; Mokrycki, E. (2010) $\mathrm{CO}_{2}$ emissions from Polish cement industry. International Journal of Greenhouse Gas Control 4, 583-588. http:// dx.doi.org/10.1016/j.ijggc.2010.02.002.

5. De Weerdt, K.; Kjellsen, K.O.; Sellevold, E.; Justnes, H. (2011) Synergy between fly ash and limestone powder in ternary cements. Cem. Concr. Comp. 33, 30-38. http:// dx.doi.org/10.1016/i.cemconcomp.2010.09.006.

6. Roy, D.M, (1999) Alkali-activated cements Opportunities and challenges. Cem. Concr. Res. 29, 249-254. http:// dx.doi.org/10.1016/S0008-8846(98)00093-3.

7. Puertas, F.; Fernández-Jiménez, A. (2003) Mineralogical and microstructural characterisation of alkali-activated fly ash/slag pastes. Cem. Concr. Comp. 25, 287-292. http:// dx.doi.org/10.1016/S0958-9465(02)00059-8.

8. Puertas, F.; Torres-Carrasco, M. (2014) Use of glass waste as an activator in the preparation of alkali-activated slag. Mechanical strength and paste characterization. Cem. Concr. Res. 57, 95-104. http://dx.doi.org/10.1016/j. cemconres.2013.12.005.

9. Sanjuán, M.Á. (2013) Los cementos ternarios y visión general del futuro de las normas de especificaciones de cementos comunes, Madrid. https://www.ieca.es/Uploads/ docs/3_Los_cementos_ternarios_y_visi\%F3n_general_ del futuro.pdf.

10. Wu, Z.; Naik, T.R. (2002) Properties of concrete produced from multicomponent blended cements. Cem. Concr. Res. 32, 1937-1942. http://dx.doi.org/10.1016/ S0008-8846(02)00907-9.

11. Carrasco, M.F.; Menéndez, G.; Bonavetti, V.; Irassar, E.F. (2005) Strength optimization of "tailor-made cement" with limestone filler and blast furnace slag. Cem. Concr. Res. 35, 1324-1331. http://dx.doi.org/10.1016/j. cemconres.2004.09.023

12. Bonavetti, V.; Donza, H.; Menéndez, G.; Cabrera, O.; Irassar, E.F. (2003) Limestone filler cement in low w/c concrete: A rational use of energy, Cem. Concr. Res. 33, 865-871. http://dx.doi.org/10.1016/S0008-8846(02) 01087-6.

13. Ortega, J.M.; Sánchez, I.; Climent, M.Á. (2013) Influence of different curing conditions on the pore structure and the early age properties of mortars with fly ash and blastfurnace slag. Mater. Construcc. 63, 219-234. http://dx.doi. org/10.3989/mc.2012.06111.

14. Bijen,J.(1996)Benefits of slagandflyash. Constr. Build. Mat 10, 309-314. http://dx.doi.org/10.1016/0950-0618(95)00014-3.

15. Menéndez, G.; Bonavetti, V.; Irassar, E.F. (2003) Strength development of ternary blended cement with limestone filler and blast-furnace slag. Cem. Concr. Composites 25, 61-67. http://dx.doi.org/10.1016/S0958-9465(01)00056-7.

16. Hale, W.M.; Freyne, S.F.; Bush Jr., T.D.; Russell, B.W. (2008) Properties of concrete mixtures containing slag cement and fly ash for use in transportation structures. Constr. Build. Mat. 22, 1990-2000. http://dx.doi.org/10.1016/j. conbuildmat.2007.07.004.

17. Ghrici, M.; Kenai, S.; Said-Mansour, M. (2007) Mechanical properties and durability of mortar and concrete containing natural pozzolana and limestone blended cements. Cem. Concr. Composites 29, 542-549. http://dx.doi.org/10.1016/j. cemconcomp.2007.04.009.

18. Yilmaz, B.; Olgun, A. (2008) Studies on cement and mortar containing low-calcium fly ash, limestone, and dolomitic limestone. Cem. Concr. Comp. 30, 194-201. http://dx.doi. org/10.1016/j.cemconcomp.2007.07.002.

19. Hoshino, S.; Yamada, K.; Hirao, H. (2006) XRD/Rietveld analysis of the hydration and strength development of slag and limestone blended cement. Journal of Advanced Concrete Technology 4, 357-367. http://dx.doi.org/10.3151/ jact.4.357

20. Elkhadiri, I.; Diouri, A.; Boukhari, A.; Aride, J.; Puertas, F. (2002) Mechanical behaviour of variuos mortars made by combined fly ash and limestone in Moroccan Portland cement. Cem. Concr. Res. 32, 1597-1603. http://dx.doi. org/10.1016/S0008-8846(02)00834-7.

21. Fernández, Á.; García Calvo, J.L.; Alonso, M.C. (2015) The Ordinary Portland Cement composition to optimize the synergies of mineral additions of ternary binders in hydration process. Cem. Concr. Comp., in evaluation.

22. De Weerdt, K.; Ben Haha, M.; Le Saout, G.; Kjellsen, K.O.; Justnes, H.; Lothenbach, B. (2011) Hydration mechanisms of ternary Portland cements containing limestone powder and fly ash, Cem Concr. Res. 41, 279-291. http:// dx.doi.org/10.1016/j.cemconres.2010.11.014.

23. Alonso, M.C.; García Calvo, J.L.; Sánchez, M.; Fernández, Á. (2012) Ternary mixes with high mineral additions contents and corrosion related properties. Materials and Corrosion 63, 1078-1086. http://dx.doi.org/10.1002/maco.201206654.

24. Dehuai, W: Zhaoyuan, C. (1997) On predicting compressive strengths of mortars with ternary blends of cement, GGBFS and Fly Ash. Cem. Concr. Res. 27, 487-493. http:// dx.doi.org/10.1016/S0008-8846(97)00039-2.

25. Schöler, A.; Lothenbach, B.; Winnefeld, F.; Zajac, M. (2015) Hydration of quaternary Portland cement blends containing blast-furnace slag, siliceous fly ash and limestone powder. Cem. Concr. Comp. 55, 374-382. http:// dx.doi.org/10.1016/j.cemconcomp.2014.10.001

26. Chindaprasirt, P.; Jaturapitakkul, C.; Sinsiri, T. (2005) Effect of fly ash fineness on compressive strength and pore size of blended cement paste. Cem. Concr. Comp. 27, 425428. http://dx.doi.org/10.1016/j.cemconcomp.2004.07.003.

27. Bogue, R.H (1929). Calculation of the compounds in Portland cement. Industrial and Engineering Chemistry 1, 192-197. http://dx.doi.org/10.1021/ac50068a006.

28. Rahhal, V.; Talero, R. (2008) Calorimetry of Portland cement with metakaolins, quartz and gypsum additions. J. Therm. Anal. Calorim. 91, 825-834. http://dx.doi. org/10.1007/s10973-006-8250-6.

29. Baert, G.; Hoste, S.; De Schutter, G.; De Belie, N. (2008) Reactivity of fly ash in cement paste studied by means of thermogravimetry and isothermal calorimetry. J. Therm. Anal. Calorim. 94, 485-492. http://dx.doi.org/10.1007/ s10973-007-8787-z.

30. Oey, T.; Kumar, A.; Bullard, J.W.; Neithalath, N.; Sant, G. (2013) The filler effect: the influence of filler content and surface area on cementitious reaction rates, J. Am. Ceram. Soc. 96, 1978-1990. http://dx.doi.org/10.1111/jace.12264.

31. Berodier, E.; Scrivener, K. (2014) Understanding the filler effect on the nucleation and growth of C-S-H, J. Am. Ceram. Soc. 97, 3764-3773. http://dx.doi.org/10.1111/jace.13177.

32. Mounanga, P.; Khokhar, M.I.A.; El Hachem, R.; Loukili, A. (2011) Improvement of the early-age reactivity of fly ash and blast furnace slag cementitious systems using limestone filler. Materials and Structures 44, 437-453. http://dx.doi. org/10.1617/s11527-010-9637-1. 
33. Torrenti, J.M.; Bendboudjema, F. (2005) Mechanical threshold of cementitious materials at early age, Materials and Structures 38, 299-304. http://dx.doi.org/10.1007/ BF02479294.

34. Gesoglu, M.; Özbay, E. (2007) Effect of mineral admixtures on fresh and hardened properties of self-compacting concretes: binary, ternary and quaternary systems. Materials and Structures 40, 923-937. http://dx.doi.org/10.1617/ s11527-007-9242-0.

35. Brooks, J.J.; Megat Johari, M.A.; Mazloom, M. (2000) Effect of admixtures on the setting times of high-strength concrete. Cem. Concr. Comp. 22, 293-301. http://dx.doi. org/10.1016/S0958-9465(00)00025-1.

36. Sáez del Bosque, I.F.; Martínez-Ramírez, S.; Blanco-Varela, M.T. (2015). Calorimetric study of the early stages of the nanosilica-tricalcium silicate hydration. Effect of the temperature. Mater. Construcc. 65. http://dx.doi.org/10.3989/ mc.2015.06814.

37. Gawlicki, M.; Nocún-Wczelik, W:; Bak, L. (2010) Calorimetry in the studies of cement hydration. Setting and hardening of Portland cement-calcium aluminate cement mixtures. J Therm Anal Calorim 100, 571-576. http:// dx.doi.org/10.1007/s10973-009-0158-5.

38. D. Jansen, F. Goetz-Neunhoeffer, B. Lothenbach, J. Neubauer (2012) The early hydration of Ordinary Portland Cement (OPC): An approach comparing measured heat flow with calculated heat flow from QXRD. Cem Concr Res, 42, 134-138. http://dx.doi.org/10.1016/j. cemconres.2011.09.001

39. Ballim, Y.; Graham, P.C. (2009) The effects of supplementary cementing materials in modifying the heat of hydration of concrete. Materials and Structures 42, 803-811. http:// dx.doi.org/10.1617/s11527-008-9425-3.

40. Soroka, I.; Stern, N. (1977) The effect of fillers on strength of cement mortars. Cem. Concr. Res. 7, 449-456. http:// dx.doi.org/10.1016/0008-8846(77)90073-4.

41. Berry, E.E.; Hemmings, R.T.; Cornelius, B.J. (1990) Mechanisms of hydration in high volume fly ash pastes and mortars. Cem. Concr. Comp. 12, 253-261. http://dx.doi. org/10.1016/0958-9465(90)90004-H.

42. Güneyisi, E.; Gesoglu, M. (2008) Properties of self-compacting mortars with binary and ternary cementitious blends of fly ash and metakaolin. Materials and Structures 41, 15191531. http://dx.doi.org/10.1617/s11527-007-9345-7.

43. Voglis, N.; Kakali, G.; Chaniotakis, E.; Tsivilis, S. (2005) Portland-limestone cement, their properties and hydration compared to those of other composite cement. Cem. Concr. Comp. 27, 191-196. http://dx.doi.org/10.1016/j. cemconcomp.2004.02.006.

44. Feldman, R.F.; Carette, G.G.; Malhotra, V.M. (1990) Studies on of development of physical and mechanical properties of high-volume fly ash-cement pastes. Cem. Concr. Comp. 12, 245-251. http://dx.doi.org/10.1016/0958-9465(90)90003-G.

45. Ben Haha, M.; De Weerdt, K.; Lothenbach, B. (2010) Quantification of the degree of reaction of fly ash. Cem. Concr. Res. 40, 1620-1629. http://dx.doi.org/10.1016/j. cemconres.2010.07.004.

46. Deschner, F.; Münch, B.; Winnefeld, F.; Lothenbach, B. (2013) Quantification of fly ash in hydrated blended Portland cement pastes by backscattered electron imaging. Journal of Microscopy 251, 188-204. http://dx.doi. org/10.1111/jmi.12061. 